\title{
Compensation for Wrongful Convictions in Canada
}

\author{
By Myles Frederick McLellan, Professor of Law and Justice, \\ Algoma University, Canada \\ Eliva Press, 2021 \\ Reviewed by Robert Home \\ Emeritus Professor \\ Anglia Ruskin University (UK)
}

\begin{abstract}
Wrongful conviction cases seem to have increased in number over recent years, publicized through popular TV documentaries, like Netflix's 'Making a Murderer' regarding the Avery case in the USA. Innocence Projects originating in the USA have spread to other countries, particularly those following the common law tradition, and new approaches to clinical legal education are being developed in the area. ${ }^{1}$ Professor McLellan has made a substantial contribution to wrongful conviction legal scholarship. Through his work, McLellan investigates an array of criminal justice issues, including the often-neglected matter of compensation.
\end{abstract}

McLellan applies Michel Foucault's theory of governmentality to develop a 'state harm risk paradigm' and draws upon the legal scholarship of John Rawls and Ronald Dworkin to show that criminal justice systems have come to favour public safety as opposed to due process. 'Exonerees' (the clumsy term for those successfully challenging conviction) create a risk for state liability to pay compensation as a moral obligation. The philosophical idea of a social contract requires a balance between the protection of individual rights and the prevention of crime in a society that is increasingly sensitive to risk. Human rights case law is expanding in the UK due to its domestication of the European Convention on Human Rights, whereas Canada has its own Charter of Rights and Freedoms. McLellan mainly focuses on Canada, but he includes a chapter on the UK and USA in his book. This reviewer, while reluctant to comment on the Canadian content, discusses the UK situation, which has continued to develop since the publication of the book.

The potential number of criminal offences that could give rise to challenge also continues to develop, as successive UK governments legislate to create new ones (although conviction challenges usually relate only to the most serious crimes). ${ }^{2}$ As a response to widely publicised miscarriages of justice, such as the Guildford Four and the Birmingham Six, the $C C R C$ started work in 1997. In these cases, the wrongfully accused were freed after serving long prison sentences for terrorist murders linked to the violent politics of Northern Ireland, receiving multi-million pound compensation payments because police evidence had been fabricated. The $C C R C$ can refer a case back to the Court of Appeal where there is a real possibility that the Court will quash the conviction (the real possibility test). Over a twentyyear period between 1997-2017, the $C C R C$ referred 634 cases back to appeals courts and about

\footnotetext{
${ }^{1}$ In the UK the Innocent Network, and the work of Michael Naughton (University of Bristol) for reform of the Criminal Cases Review Commission [CCRC].

${ }^{2}$ The potential number of criminal offences has been estimated in the UK at over 7,200, and probably many more. Justice report, Breaking the rules, British Section of the International Commission of Jurists, London (1980).
} 
two-thirds of those cases succeeded (and a further 64 appeals from 2019-2020). ${ }^{3}$ The $C C R C$ determines its workload case-by-case, allowing scope for discretion and variability, and reflecting the different professional backgrounds and personalities of its staff. ${ }^{4}$

Until 2006 awards could be made at the discretion of the Home Secretary (the so-called ex gratia scheme), but this was abolished in that year, with the intention of 'rebalancing' the criminal justice system away from the rights of defendants and towards victims; the view of the government at the time was that the biggest miscarriage of justice was when the guilty went unpunished. With many more citizens being victims of crime than those wrongfully convicted, the European Union and UK government have moved towards more support and funding for victims of crime. ${ }^{5}$ Importantly though, miscarriages of justice and wrongful conviction create victims who often experience severe psychological problems (similar to the post-traumatic stress disorders found in many war veterans). In addition to psychological damage, the Citizens Advice support service reported that a third of its clients found themselves homeless after being exonerated.

In the UK a miscarriage of justice was not defined in the Criminal Justice Act 1988, and only in the Adams case (2011, discussed by McLellan on pp 189-191), did the Supreme Court attempt to categorise it into different kinds. It identified four, as follows: where fresh evidence shows that the defendant is innocent (category 1); where fresh evidence shows that no reasonable jury could have properly convicted the defendant (category 2); where fresh evidence renders the conviction unsafe (category 3); and where something has gone seriously wrong in the investigation or the conduct of the trial (category 4). A new fact (or newly discovered fact) might show that the person could not have committed the crime in question, an example being the 'elusive silver bullet of exculpatory DNA evidence' (in McLellan's words, p 51).

Following the Adams judgment, the UK government then introduced, buried among numerous other changes in the Anti-Social Behaviour, Crime and Policing Act 2014 (Part 13), an amendment to the 1988 Act that severely restricts eligibility for compensation after miscarriages of justice. These were now confined to only the first category in the Adams judgment: 'if and only if the new or newly discovered fact shows beyond a reasonable doubt that the person did not commit the offence ${ }^{6}{ }^{6}$ The perfunctory government impact assessment that preceded this change had offered only two options: 'do nothing' (continue to rely upon case law), and legislation 'to ensure that eligibility to the scheme is limited to applicants who can show that they are clearly innocent'. The government arguing that this would ensure 'a more predictable and consistent approach', give a 'settled meaning' to the term miscarriage of justice, and reduce 'unmeritorious claims' and legal challenges. ${ }^{7}$ The change, which was severely

\footnotetext{
${ }^{3}$ United Kingdom, House of Commons, Justice - Twelfth Report (UK: Criminal Cases Review Commission, 2015), online: <https://publications.parliament.uk/pa/cm201415/cmselect/cmjust/850/85002.htm>. See also Jon Robins, "The Law is Broken" (2018) 168:7792 New LJ 7.

4 Annabelle James, Nick Taylor \& Clive Walker, "The Criminal Cases Review Commission: Economy, effectiveness and justice" (2000) Crim L Rev 140 at 140-153.

${ }^{5}$ UK Government, Victims Strategy, (2018), Cmd. 9700. EU Council Directive 2004/80/EC (compensation to crime victims) and EU Strategy on victims' right 2020-2025, COM (2020) 258. Fifteen million serious offences occurred in the EU in 2017.

${ }^{6}$ By amending section 133 of the 1988 Act with subsection 1ZA. See Carolyn Hoyle \& Laura Tilt, "Not Innocent Enough: State compensation for miscarriages of justice in England and Wales" (2019) 2020:1 Crim L Rev 29 at 29-51

${ }^{7}$ Impact assessment: Clarifying the circumstances under which compensation is payable for Miscarriages of Justice (England \& Wales) (UK: Ministry of Justice, 2013), online:
} 
criticised at the time by lawyers specialising in such cases, had the effect of significantly reducing the number of compensation applications and the value of payments: the Ministry of Justice received a mere 157 applications in 2018-19 and paid out only $£ 10,000$, compared to the hundreds of successful cases and millions paid out in earlier years. ${ }^{8}$ Over the last five years there has been only five successful applications for compensation, which is determined by an independent assessor. Payments are now not to exceed $£ 1$ million when the claimant had been detained in prison or hospital for over ten years, or $£ 500,000$ in all other cases; there are caps on loss of earnings, and deduction for 'saved living expenses' while in prison (which could have made claimants better off than if they had remained free).

The issue of compensation subsequently arose with the Nealon and Hallam cases (discussed by McLellan, pp 191-193). These individuals succeeded in getting their convictions quashed because of poor forensic evidence, no CCTV footage, and disclosure failures, but received no compensation, no apology, nor even an explicit acknowledgment that they were innocent. The conjoined cases went to the UK Supreme Court, which rejected their arguments, finding in 2019 by a majority of five to two that the UK compensation scheme complied with Article 6 (2) of the European Convention on Human Rights (the presumption of innocence). ${ }^{9}$ The cases involved complex jurisprudence and divergent judicial interpretations, and are currently under referral to the European Court of Human Rights; this leads to long delays due to a backlog of cases. ${ }^{10}$ (The UK remains under that court's jurisdiction even after Brexit, under the political declaration accompanying the 2018 withdrawal agreement.)

The wider issue remains controversial and it is unfortunate (although no fault of his) that Professor McLellan's book was published before the UK All-Party Parliamentary Group on Miscarriages of Justice published its 'Westminster Commission' report in February 2021. ${ }^{11}$ That study by high-level judicial experts, meticulously researched and evidenced, showed that the risk of wrongful conviction in the UK is as great now as it was before the CCRC was created as the place of last resort when all else fails. The timing of the report's publication was unfortunate, as the country was still under the Covid-19 lockdown, and the criminal justice system was experiencing severe stress because of sustained under-investment and a court backlog of cases. The Covid-19 pandemic is contributing to a rise in domestic violence and other crimes, and its future impact upon public finances is expected to be huge. Meanwhile the compensation system in Canada, the US and UK (and doubtless elsewhere) still needs overhaul if it is to ensure public confidence in the judicial system, yet politicians and legislators show

<https://assets.publishing.service.gov.uk/government/uploads/system/uploads/attachment_data/file/197579/DO C002.PDF>. See also Miscarriages of Justice: compensation schemes (UK: House of Commons Library Note SN/HA/2131, 2015), online: 〈https://commonslibrary.parliament.uk/research-briefings/sn02131/〉

8 Jon Robins, "Shameful: Just $£ 10,000$ Paid Out to Victims of Wrongful Conviction in Two Years," The Justice Gap (23 Oct 2020), online: <https://www.thejusticegap.com/shameful-just-10000-paid-out-to-victims-ofwrongful-conviction-in-three-years/>

${ }^{9} R$ (Hallam) $v$ Secretary of State for Justice, and $R$ (Nealon) $v$ Secretary of State for Justice, [2019] UKSC 2, [2020] AC 279, online: 〈https://www.supremecourt.uk/cases/docs/uksc-2016-0227-judgment.pdf>. One of the Supreme Court judges suggested that Hallam, a teenager at the time, was the architect of his own misfortune because of his 'dysfunctional lifestyle'.

${ }^{10}$ Jon Robins, "Miscarriage of Justice Body’s Workload Doubled Despite Severe Cuts - Report," The Guardian (5 Mar 2021), online: <https://www.theguardian.com/law/2021/mar/05/miscarriage-of-justice-bodys-workloaddoubled-despite-severe-cuts-report>. See also Hannah Quirk, "Compensation for Miscarriages of Justice: Degree of Innocence” (2020) 79:1 Camb LJ 4 at 4-7, online: 〈https://doi.org/10.1017/S0008197320000136>.

${ }^{11}$ United Kingdom, The Westminster Commission on Miscarriages of Justice, In the Interests of Justice: An Inquiry into the Criminal Cases Review Commission (London: All-Party Parliamentary Group, 2021) at 1-89, online: $<$ https://appgmiscarriagesofjustice.files.wordpress.com/2021/03/westminster-commission-onmiscarriages-of-justice-in-the-interests-of-justice.pdf $>$ 
little appetite for further reform. A post-Brexit UK wants to be in charge of its own legal rights, and in doing so, diminishes the ability of citizens to challenge their government. As such, miscarriages of justice in the UK today are as likely to occur as when the $C C R C$ was created a quarter of a century ago. A mature criminal justice system is one with humility, unafraid to admit and apologise for its mistakes, and allow an independent body to quash convictions and determine compensation - but that seems unlikely for some time.

The difficulty of correcting and compensating for wrongful convictions is compounded by both a human and an institutional reluctance to admit being wrong. The so-called Semmelweis reflex applies: when Hungarian doctor Ignaz Semmelweis discovered in 1847 that hand-washing by hospital doctors dramatically reduced child-birth mortality rates, his recommendations were rejected despite overwhelming empirical evidence. ${ }^{12} \mathrm{~A}$ similar concept is belief perseverance (or conceptual conservatism): the tendency for people to retain stronglyheld beliefs long after these beliefs have been discredited; this is due to the difficulty in rearranging their conceptual and cognitive framework. ${ }^{13}$ The discovery of important scientific fact may be punished, as happened to Galileo when the Catholic Church found heliocentrism (that the planet revolved around the sun) foolish, absurd, and heretical because it contradicted holy scripture. ${ }^{14}$ Psychiatrist Thomas Szasz wrote about his own 'deep sense of the invincible social power of false truths', and those false truths were demonstrated by the conspiracy theorists and Trump supporters attacking the US Capitol building in January 2021. ${ }^{15}$ Not only people - professionals and scientists - but also institutions may refuse to admit mistakes. A belief culture among police, prosecutors, and courts that too many guilty individuals are getting acquitted can lead to the rules of due process being perverted and wrongful convictions going uncorrected and uncompensated for even when corrected.

Myles McLellan has done the legal community, both in Canada and elsewhere, a service with this well-researched and argued book. The discussions of case law, and the appendices that produce statements of claim in three Canadian cases which illustrate (respectively) issues of malicious prosecution, negligent investigation, and constitutional tort, are particularly strong. He also presents a model for a 'Compensation for Wrongful Convictions Act', drafted as if for the Canadian province of Manitoba, although the road to legislative reform may prove long and hard. Minor criticisms of the book are that the index and bibliography could be easier to use, but this should not detract from his achievement. By including more on the experience of other jurisdictions beyond the common law systems, future editions could reach a wider readership.

\footnotetext{
12 Some doctors refused to believe that a gentleman's hands could transmit disease. Semmelweis' continued rejection made him mentally ill, and he died in 1865 in an asylum, ironically of septicaemia after being beaten by his warders. Timothy Leary \& Robert A Wilson, The Game of Life, (USA: New Falcon Publications, 1991).

${ }^{13}$ Moti Nissani, “Conceptual conservatism: An understated variable in human affairs?” (1994) 31:3 Soc Sci J 307 at 307 .

${ }^{14}$ Christopher M Graney, Setting Aside All Authority: Giovanni Battista Riccioli and the Science against Copernicus in the Age of Galileo, ${ }^{\text {st }}$ (USA: University of Notre Dame Press, 2015).

15 Thomas S Szasz, The Myth of Mental Illness: Foundations of Theory of Personal Conduct, (NY: Harper Perennial, 1980).
} 